\title{
Aboveground Biomass Production and Nitrogen Content of Gliricidia Sepium under Different Pruning Regime- A Case Study at the Department of Agroforestry Farm (Kwame Nkrumah University of Science and Technology-KNUST)
}

\author{
Christian Tettey Agbana \\ Department of Agroforestry \\ Kwame Nkrumah University of Science and Technology, \\ KNUST, Kumasi, Ghana
}

\begin{abstract}
Gliricidia sepium is considered one of the commonly used multipurpose legume shade trees in Ghana. Different pruning regimes affect the nutrient content as the amount of biomass produced by many multipurpose trees. In this study, the aboveground biomass (both fresh and dry matter) production and nitrogen content in Gliricidia sepium under different pruning regimes $(4,8$ and 12 weeks) was studied. The study was carried out in the demonstration farm of Department of Agroforestry in the Faculty of Renewable Natural Resources-KNUST. A total of nine (9) Gliricidia trees were selected. The pruning frequencies were assigned to the selected trees, after an initial pruning of $1.2 \mathrm{~m}$ from the ground. The data collected include; new fresh weight, dry weight and nitrogen content at the various pruning time. Also, the amount of nitrogen $(\mathrm{N})$ in the new biomass was estimated at each pruning time. The result shows that the aboveground biomass production increased from 4 weeks to 12 weeks regime. Overall nitrogen concentration increased from $2.61 \%$ to $3.58 \%$ upon reducing the pruning frequency from 4 to 12 weeks, and total nitrogen content was much higher in 12 weeks (36.01g) than in the other pruning frequencies, due to biomass production been larger. In conclusion, the study highlights the potential of Gliricidia biomass as a source of $\mathbf{N}$ and green manure for both agricultural and agroforestry purposes. Hence pruning regime of Gliricidia should be considered in managing it for nutrient and manure purposes.
\end{abstract}

Keywords:- Gliricidia sepium, Aboveground Biomass Prodcution, Nitrogen, Pruning, Kjeldahl Method.

\section{INTRODUCTION}

Gliricidia sepium is considered one of the commonly used multipurpose legumes shade trees [13]. Gliricidia sepium is naturalized widely in the tropical Americas, the Caribbean, Asia, Africa and the Pacific islands [8]. The size of the tree is usually controlled by regular pruning in the cultivation environment. The tree typically grows to $10 \mathrm{~m}$ (33ft) and occasionally reaching $15 \mathrm{~m}$ (50ft) in height, with a
Elvis Wireko Boampong

Department of Environmental and Safety Engineering University of Mines and Technology, UMaT, Tarkwa, Ghana

broad canopy [4]. It grows best in a warm, seasonally dry climate with $900 \mathrm{~mm}-1500 \mathrm{~mm}$ (55-60in) annual rainfall and elevation 0-1200m (0-4000ft). It can withstand drought, full sun, shade, fire, salt spray, frost, wind, waterlogging, etc. It is easily established from cuttings and seeds, although seed establishment is needed when used in situ because of deeper rooting [4]. Nutrient content varies with age, season and physiological state (before and after flowering) in Gliricidia sepium [14]. It is rich in nutrients $(\mathrm{C}, \mathrm{K}, \mathrm{P}, \mathrm{N}, \mathrm{Mg}, \mathrm{Fe}, \mathrm{Ca}$, etc.) and it is a good nitrogen fixer, although not as good as Erythrina peoppigiana and Leucaena leucocephala [4]. Gliricidia sepium in hedges around crops are pruned regularly to control shade, provide fodder, green manure, firewood, or stakes for fences but nitrogen fixation is the main reason for the pruning [9].

Pruning and pollarding are the main management activities used on Gliricidia sepium. Pruning at $0.3-1.5 \mathrm{~m}$ will stimulate leaf production whilst pollarding at $2 \mathrm{~m}$ or above is known for optimal wood biomass production [10]. In most cocoa agroforestry systems, Gliricidia sepium is used as shade tree due to the low concentration of lignin and action polyphenol in their biomass, which enhances the decomposition of their biomass when used as green manure [6]. Water holding capacity, nutritional status and bulk density of soil can be increased by a decomposed litter of Gliricidia sepium [15].

In the tropics, poor soil fertility and moisture stress have been the constraints with crop production. In agroforestry, trees are used on the same field with crops for multipurpose (nutrient fixation, windbreak, safety net, nutrient pump, etc.) reasons [2].

Meanwhile, in Ghana, many potential trees biomass (which can help improve and conserve the soil) remain underutilized due to limited research and knowledge transfer [12]. However, several studies have shown that biomass production in nitrogen-fixing leguminous trees such as Gliricdia sepium might be influenced by the frequency and height of pruning [8]. Most farmers use Gliricidia sepium as a shade tree in their farms and prune the biomass as green manure to improve the fertility of their farmlands [13]. 
Hence, the need to conduct this study to provide useful information for farmers to prune using the appropriate regime. This current study is aimed at assessing the effect of three pruning regimes (at 4, 8 and 12weeks interval) on the Gliricidia sepium aboveground biomass production and nitrogen content. The study will help in finding out if regular pruning of Gliricidia sepium can affect the amount of biomass it produces and the nitrogen concentration. This will serve as a recommendation to farmers on how frequently they should prune Gliricidia sepium to use the biomass as organic manure (green manure).

\section{STUDY AREA}

The experiment was conducted at the Department of Agroforestry in the Faculty of Renewable Natural Resources Research Farm, KNUST from the period of December 2018 to March 2019. This site falls under the Moist Semideciduous Forest Zone. The annual rainfall of the site ranges from 1500-2000mm. The major rainy season starts in March and lasts until July. This is followed by the minor rainy season which starts in September and ends in November. The daily average temperature is $25.6{ }^{\circ} \mathrm{C}$, with the warmest average temperature of $33{ }^{\circ} \mathrm{C}$ in March and the lowest average temperature of $20{ }^{\circ} \mathrm{C}$ in January, February and December. The soils in the site belong to the family Ferric Acrisols in the soil taxonomy [1].

\section{METHODOLOGY}

\section{A. Experimental Procedure}

The experimental procedure was done according to the recommendations of Marroquin et al. 2005.

A total of nine (9) Gliricidia sepium trees were selected from the Farm. Pruning frequency, with three levels (4, 8 and 12 weeks) was assigned to the selected trees and pruning height, with one level (1.2m stem from the ground) was used. On $20^{\text {th }}$ December 2018, all the foliages and branches of the 9 selected trees were pruned from the ground level, leaving only one main stem at a height of $1.2 \mathrm{~m}$. Starting from that date, the pruning regimes were applied systematically in each of the experimental units during the 12-weeks cycle. Hence, at 4 weeks after the initial pruning, 3 out of the 9 Gliricidia sepium trees were selected and pruned. This procedure was repeated at 8 weeks and finally at 12 weeks.

In each experimental unit, the total fresh weight of foliage and branches was quantified separately at each harvest and was taken for further analysis. At the laboratory, samples were oven-dried at $70^{\circ} \mathrm{c}$ until constant weight. Using the dry/fresh weight ratio of the sample, total dry matter (grams) of biomass (foliage and branches) was estimated for each sample.

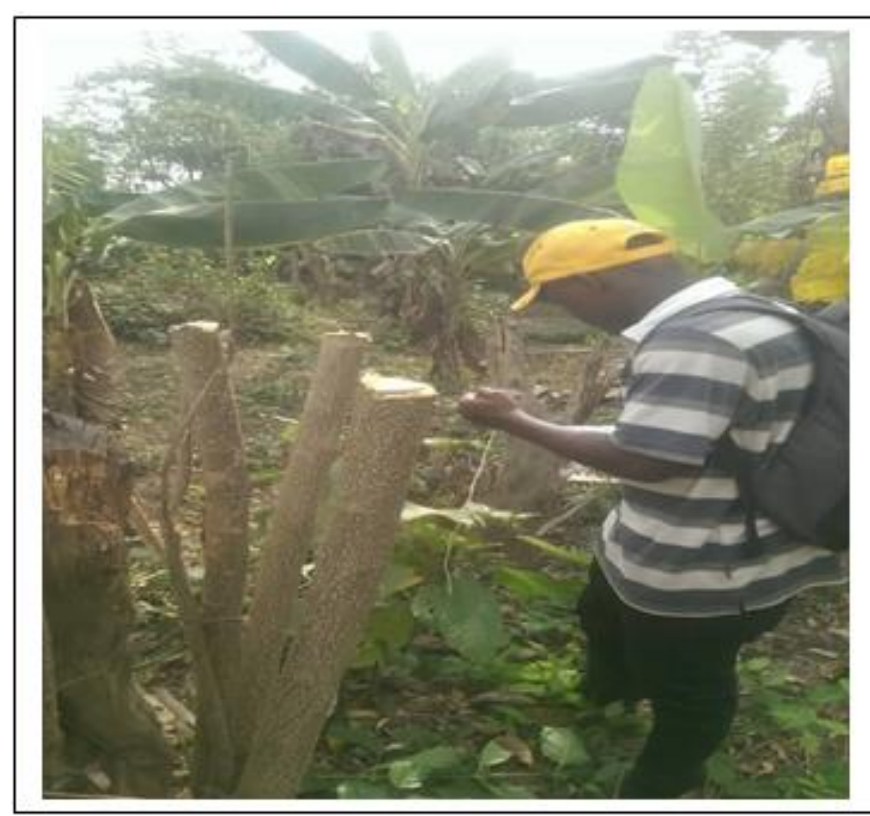

Fig 1:- Tagging of Gliricidia sepium trees after initial pruning

\section{B. Determination of Nitrogen (KJELDAHL Method) \\ $>$ Principle:}

Nitrogen $(\mathrm{N})$ is the major element next to $\mathrm{C}, \mathrm{H}$ and $\mathrm{O}_{2}$ found in living things. In most proteins, $\mathrm{N}$ constitutes $16 \%$ of the total make-up. The micro-Kjeldahl technique was adopted to estimate the total $\mathrm{N}$ content in the variety of samples collected at each pruning regime. With this method, the $\mathrm{N}$ in protein or any other organic material is converted to ammonium sulfate by $\mathrm{H}_{2} \mathrm{SO}_{4}$ digestion. This salt, on steamdistillation, liberates $\mathrm{NH}_{3}$ which is collected in boric acid solution and titrated against standard acid. Since $1 \mathrm{ml}$ of $0.1 \mathrm{~N}$ acid is equivalent to $1.401 \mathrm{mg} \mathrm{N}$, the calculation is made to arrive at the $\mathrm{N}$ content of the sample. It is assumed that the $\mathrm{N}$ is derived from protein-containing $16 \% \mathrm{~N}$ and multiplying the $\mathrm{N}$ figure by $100 / 16$ or 6.25 , an approximate protein value is obtained.

\section{> Apparatus:}

- Kjeldahl flasks: $500 \mathrm{ml}$ hard glass flasks or $10 \mathrm{ml}$ size for micro-sample.

- Digestion rack: commercial heating apparatus

- Distillation apparatus Volumetric flask

- Conical flask, $200 \mathrm{ml}$

$>$ Reagent:

- Conc. $\mathrm{H}_{2} \mathrm{SO}_{4}$ (ammonia-free grade)

- $40 \% \mathrm{NaOH}$

- $4 \%$ Boric acid solution $\left(\mathrm{H}_{3} \mathrm{BO}_{3}\right)$

- Catalyst:

$\checkmark$ selenium: 1

$\checkmark$ copper sulfate $\left(\mathrm{CuSO}_{4}\right): 10$

$\checkmark$ Potassium or sodium sulfate $\left(\mathrm{K}_{2} \mathrm{SO}_{4} / \mathrm{Na}_{2} \mathrm{SO}_{4}\right): 100$

- Mixed indicator or Bromocresol green and methyl red in ethyl alcohol

- $1 \mathrm{~N} \mathrm{Standard} \mathrm{HCl}$ 


\section{$>$ Digestion:}

- Weigh $1 \mathrm{~g}$ of the sample into a 500ml long-necked Kjeldahl flask.

- Add $10 \mathrm{ml}$ distilled water to moisten the sample.

- Add one spatula full of Kjeldahl catalyst [a mixture of 1 part Selenium +10 parts $\mathrm{CuSO}_{4}+100$ parts $\left.\mathrm{Na}_{2} \mathrm{SO}_{4}\right]$

- Add $10 \mathrm{ml}$ conc. $\mathrm{H}_{2} \mathrm{SO}_{4}$

- Digest until clear and colorless

- Allow flask to cool

- Decant fluid into a $100 \mathrm{ml}$ volumetric flask and makeup to the mark with distilled water.

\section{$>$ Distillation:}

- Transfer an aliquot of $10 \mathrm{ml}$ of fluid through pipette into the Kjeldahl distillation apparatus provided.

- Add $90 \mathrm{mls}$ of distilled water to make it up to $100 \mathrm{ml}$ in the distillation flask.

- Add or Dispense $20 \mathrm{ml}$ of $40 \% \mathrm{NaOH}$

- Collect distillate over $10 \mathrm{ml}$ of $4 \%$ Boric acid and three (3) drops of mixed indicator in a $200 \mathrm{ml}$ conical flask. (Collect 100ml)

NB: The presence of Nitrogen gives a light blue color.

\section{$>$ Titration:}

- Titrate collected distillate $(100 \mathrm{ml})$ with $0.1 \mathrm{~N} \mathrm{HCl}$ till blue color changes to grey and then suddenly flashes to pink.

NB: A blank determination must necessarily be carried out without the sample.

\section{Calculation:}

NB: Weight of sample used, considering the dilution and the aliquot taken for distillation

$$
\frac{2 g * 10 m l}{100 m l}=0.2 g
$$

Thus, the percentage of Nitrogen in the plant sample is;

$$
\% N=\frac{14 *(A-B) * N * 100}{100 * 0.2}
$$

Where:

$\mathrm{A}=$ volume of standard $\mathrm{HCl}$ used in the sample titration

$\mathrm{B}=$ volume of standard $\mathrm{HCl}$ used in the blank titration

$\mathrm{N}=$ Normality of standard $\mathrm{HCl}(0.1 \mathrm{~N})$

\section{Data Collection}

Data was collected on,

- Weight of fresh biomass produced by each sample and combination of the three samples at each pruning regime.

- Weight of dry biomass produced by each sample and combination of the three samples at each pruning regime.

- Nitrogen content in each sample and the three-sample combined in each pruning regime.

\section{Data Analysis}

The data was analyzed using Statistix 10 and analysis of variance to determine the effect of the pruning regime on the variable measured at $\mathrm{p} \leq 0.05$.

The mean was separated using least significance difference. The result was presented in tables and graph.

\section{RESULT}

\section{A. Biomass Production}

Analysis of variance showed a significant ( $\mathrm{p} \leq 0.05)$ difference in fresh biomass weight of Gliricidia sepium between pruning at 4 weeks and week 12. Also, there was no significant $(\mathrm{p} \geq 0.05)$ difference between pruning at week 4 and 8, and also week 8 and 12 (Figure 4.1). However, the dry biomass weight of Gliricidia at the different pruning regimes showed no significant $(\mathrm{p} \geq 0.05)$ difference (Figure 4.2). Generally, both fresh and dry biomass increased as pruning frequency decreased, with the highest fresh and dry biomass recorded at 12 weeks whilst the lowest was at 4 weeks (Figure 4.1 and 4.2).

The pruning frequency (week) influenced the aboveground fresh and dry biomass production of Gliricidia sepium. Increasing of aboveground biomass production (both fresh and dry) at week 4 through to week 12 is in accordance with [3] who reported biomass production increased with decreasing pruning frequency (week), which might support a hypothesis that the three pruning regimes will have a different increase in Gliricidia sepium biomass production. Furthermore, [8] confirmed that total biomass production in Gliricidia sepium grown in Mexico drastically increased upon reducing the pruning frequency from weeks 4 to week 24 .

From the results (mean fresh and dry biomass), week 4 from the first pruning had the shortest interval compared to week 8 and 12. This is reflected in biomass production each week. Week 4 produced the lowest amount of biomass followed by week 8 and week 12 producing the highest biomass, which is in agreement with [5] who stated that frequent cutting decreases biomass production in agroforestry trees.

According to [7], repeated plant defoliation at short intervals depleted reserve carbohydrates. [5] observation were in support of [7] assertion when they worked on the interaction among cutting frequency, reserve carbohydrates and post-cutting biomass production in Gliricidia sepium and L. leucocephala in Ibadan, Nigeria. They found out that the concentration of starch and total reserve carbohydrates progressively decreased in Gliricidia sepium and Leuceana leucocephala due to frequent cutting and which was also linearly correlated to dry biomass production. This idea is strongly supported by the evidence that plants mobilize reserve carbohydrates to rebuild photosynthetic tissue after cutting, defoliation, or seasonal loss of foliage. It is therefore assumed reasonably that if trees are cut too frequently; reserve carbohydrates will be depleted unless 
sufficient time for replenishment is allowed between cut [11].

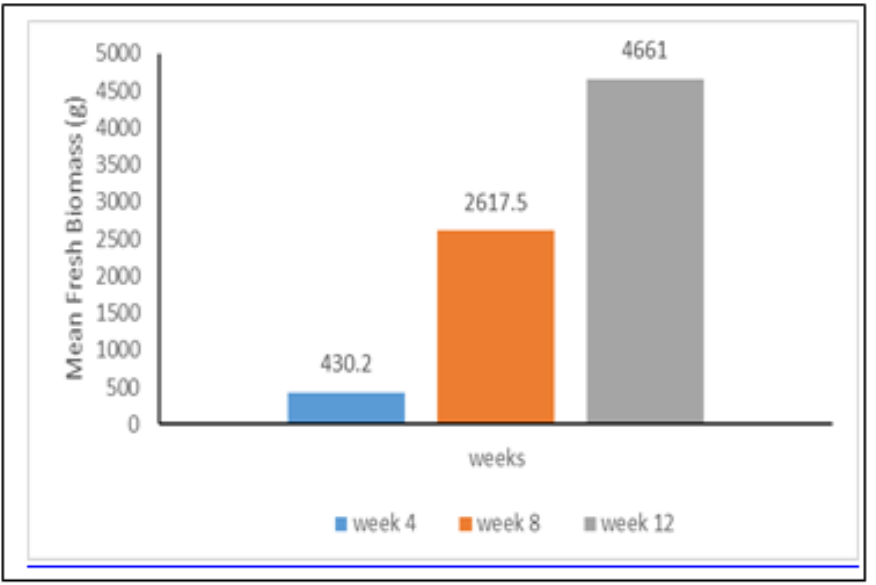

Fig 2:- The mean fresh biomass production of Gliricidia sepium at different pruning regimes.

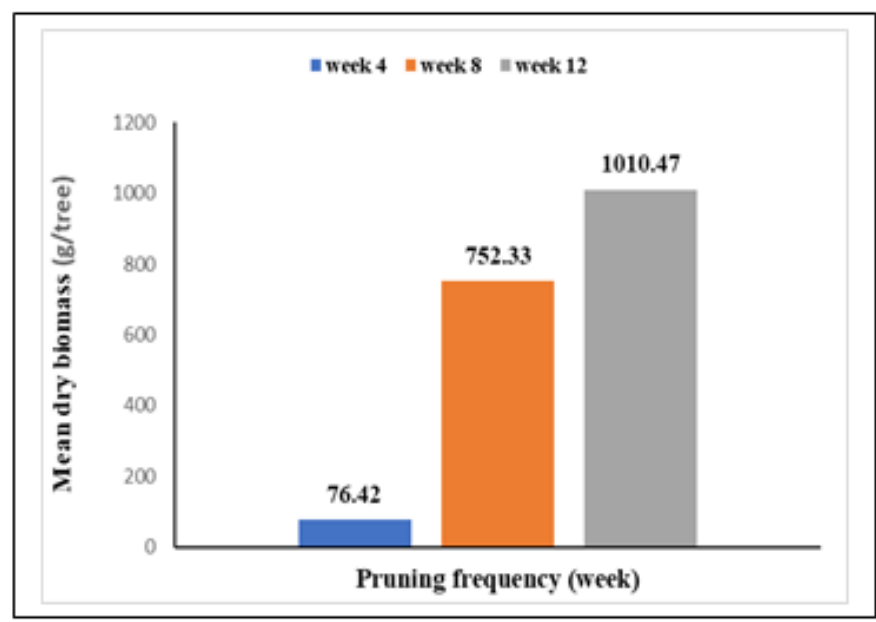

Fig 3:- The mean dry biomass production of Gliricidia sepium at different pruning regime.

\section{B. Nitrogen Concentration and Amount}

The result showed a significant $(\mathrm{p} \leq 0.05)$ difference in $\mathrm{N}$ concentration (\%) between pruning at 4 weeks and week 12 , but no significant $(\mathrm{p} \geq 0 / 05)$ difference between week 4 and 8 and also Week 8 and 12 .

Biomass quality (nitrogen concentration, \% NC) increased with the gradual reduction in pruning frequency (week), which is not in agreement with the findings of [8] who reported \% $\mathrm{NC}$ decreases with the gradual reduction in pruning and also stated that the higher $\% \mathrm{NC}$ was found in week 4 pruning regime.

Table 1 shows how the amount of nitrogen was computed at each pruning regime. The amount of $\mathrm{N}(\mathrm{g})$ was also significantly $(\mathrm{p} \leq 0.05)$ difference between week 4 and 12 but there was no significant $(\mathrm{p} \geq 0.05)$ difference in week 4 and 8 , week 8 and 12 in the three pruning regimes (Figure $5)$. Both nitrogen concentration and the amount of $\mathrm{N}$ increased as pruning frequency decreased (Figure 4 and 5).
The contrary observation in my studies can be explained by the high metabolic and expansion rates that developing leaves commonly have, which represent a strong sink for nitrogen $(\mathrm{N})$ compounds.

However, the increased in nitrogen content as pruning frequency was reduced which is in accordance [8] who reported that total nitrogen content increased as pruning frequency reduced, which can be attributed to the large increase in aboveground biomass obtained despite the reduction in nitrogen concentration associated to these lower-frequency pruning regimes.

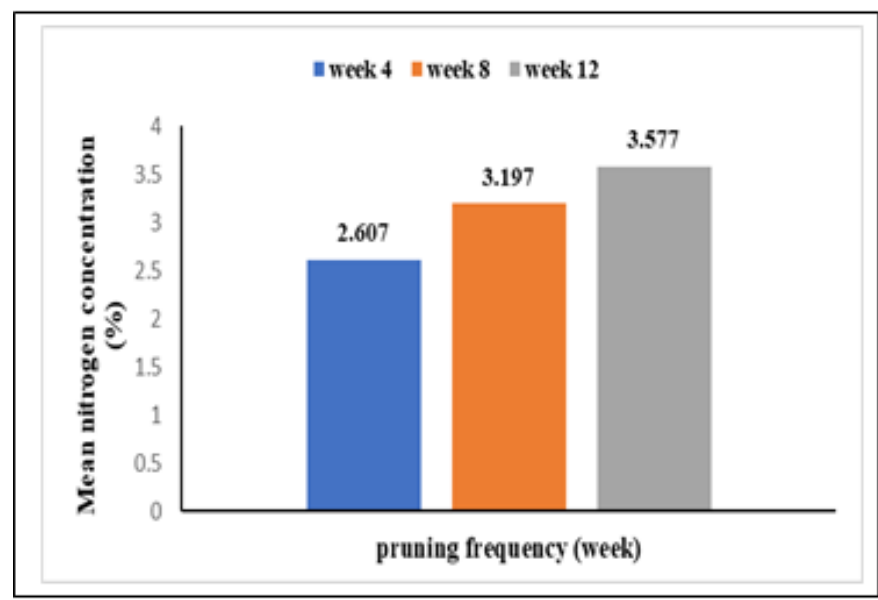

Fig 4:- The mean nitrogen concentration at the end of the experiment

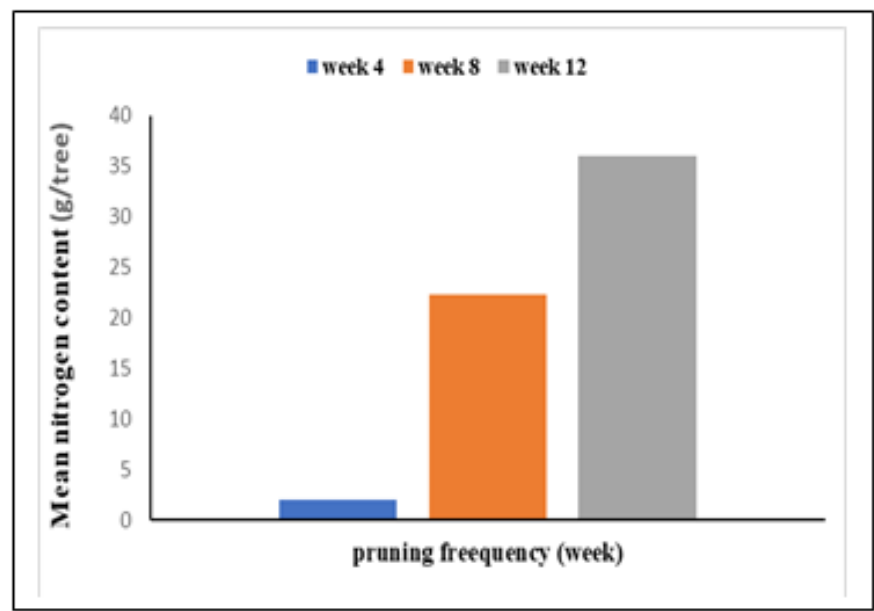

Fig 5:- The mean nitrogen amount at the end of the experiment

\begin{tabular}{|c|c|c|c|}
\hline \multirow[b]{2}{*}{$\begin{array}{c}\text { Pruning } \\
\text { Weeks }\end{array}$} & \multicolumn{3}{|c|}{ Biomass Production and Nitrogen Content } \\
\hline & $\begin{array}{c}\text { Biomass } \\
(\text { D. W })\end{array}$ & $\begin{array}{c}\text { Nitrogen } \\
\text { Concentration } \\
(\%)\end{array}$ & $\begin{array}{c}\text { Nitrogen } \\
\text { Amount }(g)\end{array}$ \\
\hline 4 & 76.4 & 2.607 & 2.003 \\
\hline 8 & 752.3 & 3.179 & 22.340 \\
\hline 12 & 1010.500 & 3.577 & 36.010 \\
\hline
\end{tabular}

Table 1:- Estimation of the amount of nitrogen $(\mathrm{g} / \mathrm{tree})$ in Gliricidia sepium biomass (D.W) at different pruning regimes. 


\section{CONCLUSION AND RECOMMENDATION}

\section{A. Conclusion}

One of the benefits of multipurpose leguminous trees in an agroforestry system is to provide nutrients (particularly nitrogen) for the system to work profitably. This can be achieved when the aboveground biomass of the trees is pruned periodically and incorporated to the soil or used as fodder to feed animals. Pruning also can affect the amount of aboveground biomass production. Even though the study did not include incorporating the pruned biomass to determine soil organic matter (SOM) and soil nitrogen (SN) to crops it was shown that with a 12-weeks pruning regime Gliricidia sepium would incorporate about $144.04 \mathrm{gN}$ per year. These results highlight the potential of Gliricidia sepium biomass as a source of green manure for agriculture and agroforestry purposes. The pruning regime of Gliricidia sepium has to be considered in the management of this agroforestry system because the pruning frequency (week) affects the aboveground biomass production and its quality $(\% \mathrm{NC})$.

\section{B. Recommendation}

From the study, it is recommended that:

- Farmers can prune Gliricidia sepium at an interval of 12 weeks as a source of green manure or fodder for their livestock. This can help to save money from buying inorganic fertilizers to improve soil fertility and also processed feed to feed their livestock.

- Further research can be done to assess the rate at which the biomass of Gliricidia sepium produced at each pruning regime will decompose to release the nitrogen and other nutrients into the soil for crops to benefit.

\section{LIMITATION}

Required information such as the actual ages of the tree, number of times the trees have been previously pruned, different cropping systems before and after the establishment of the trees was not available.

\section{ACKNOWLEDGMENT}

The authors would like to acknowledge the assistance of Dr. James Seutra Kaba, the Laboratory and Farm technicians at the KNUST Agroforestry Department towards this work.

\section{REFERENCES}

[1]. Adu, S. V. and Asiamah R. D., (1992). Soils of the Ayensu-Densu Basin, Central, Eastern and Greater Accra Regions of Ghana. Council for Scientific and Industrial Research (CSIR) - Soil Research Institute Memoir No. 9. 117 pp.

[2]. Anim-Kwapong, G. J. (2003). Potential of some Neotropical Albizia species as shade trees when replanting cacao in Ghana. Agroforestry Systems, $58(3)$,

185-193.
[3]. Duguma B, Kang B .T, Okali D .U. (1988). Effect of pruning intensities of three woody leguminous species grown in alley cropping with maize and cowpea on an alfisol. Agrofor. Syst. 6: 19-35.

[4]. Elevitch, C.R. and Francis, J.K., 2006. Gliricidia sepium (gliricidia). Species profile for Pacific Island agroforestry.(Ed. C. R Elevitch). Permanent Agriculture Resources. Hawaii. http://www. traditionaltree. org.[01/09/2011].

[5]. Handayanto E, Cadish G, Giller KE (1994). Nitrogen release from prunings of legume hedgrow trees in relation to quality of the prunings and incubation method. Plant soil, 160: 237-248

[6]. Harrington MG (1989) Gambel oak root response to spring, summer, and fall prescribed burning. J Range Manag 42:504-507

[7]. Latt CR, Nair PKR, Kang BT (2000) Interactions among cutting frequency, reserve carbohydrates, and post-cutting biomass production inGliricidia sepiumand Leucaena leucocephala. Agrofor Syst 50:27-46

[8]. Marroquín, I. M., Hernández, J. V., Martínez, A. V., \& Barra, J. E. (2005). Aboveground biomass production and nitrogen content in Gliricidia sepium (Jacq.) Walp. Under several pruning regimes. Interciencia, 30(3), 151-158.

[9]. Motis, T. (2007). Agroforestry Pricncoples. ECHO Technical Note, 1-11. Retrieved from echo@echonet.org.

[10]. Orwa C, A MUtua, Kindt R ,Jamnadass R, S. A. (2009). Gliricidia sepium Gliricidia sepium ( Jacq .) Walp . Fabaceae - Papilionoideae. Agroforestry Database 4.0(Orwa et Al., 2009), 0, 1-6.

[11]. Partey S. T., Quashie-Sam S. J., Thevathasan N. V., and Gordon A. M (2010). Decomposition and nutrient release patterns of the leaf biomass of the wild sunflower (Tithonia diversifolia): a comparative study with four leguminous agroforestry species. Agroforest Syst 81:123-134.

[12]. Partey, S. T., \& Thevathasan, N. V., (2013). Agronomic potentials of rarely used agroforestry species for smallholder agriculture in Sub-Saharan Africa: an exploratory study. Communications in soil science and plant analysis, 44(11), 1733-1748.

[13]. Somarriba, E., \& Beer, J. (2011). Productivity of Theobroma cacao agroforestry systems with timber or legume service shade trees. Agroforestry Systems, 81(2), 109-121. http://doi.org/10.1007/s10457-0109364-1

[14]. Speedy, A. W. (2011). The Development of the FAO Tropical Feeds Information System. Tropical Feeds and Feeding Systems, 9-21.

[15]. Wani S.P., Sreedevi T.K., Rockström J. and Ramakrishna Y.S. (2009). Rainfed Agriculture - Past trend and future prospectus. In: Wani SP, Rockström J and Oweis T (eds) Rainfed agriculture: Unlocking the Potential. Comprehensive Assessment of Water Management in Agriculture Series. CAB International, Wallingford, UK, pp. 1-35. 